\title{
North East Region and Arunachal Pradesh (India) - Looking beyond \& within in Pursuit to Promote Entrepreneurship
}

\author{
Sukamal Deb \\ Ministry of Micro, Small \& Medium Enterprises, Khadi \& Village Industries Commission, Government of India, India
}

Copyright $\mathrm{O} 2018$ by authors, all rights reserved. Authors agree that this article remains permanently open access under the terms of the Creative Commons Attribution License 4.0 International License

\begin{abstract}
Entrepreneurs shape economic destiny of nations. Their innovative ideas are major source of competitiveness in an increasingly globalizing world economy. Without a strong entrepreneurial community the developing countries will not prosper despite their rich resource endowments. India is a young country with about 63 per cent population in the working age group. This demographic dividend needs to be en-cashed with priorities. Engagements of the youths in creative pursuits, embracing entrepreneurship will bring steadiness to the growth curve and socio-economic transformation. Regional disparities of this country are an issue of concern. In this context focus on the North East Region in general and the state of Arunachal Pradesh in particular are more relevant. The problem of this region can be tackled by harnessing entrepreneurship, by promoting Micro and Small Enterprises. This needs creation of an ecosystem grooming the youths with the relevant skills, inspiring motivation, igniting entrepreneurship and innovations. The present century has thrown up unfamiliar challenges. The pace of change has been fast and our youths have to synchronize them to face these challenges at fast track. An essential way to motivate youths is to celebrate their entrepreneurship, their innovations and their stories of success need to be told.
\end{abstract}

Keywords Entrepreneurship, North East Region, Arunachal Pradesh, Skill Development, Tribal

\section{Introduction}

Entrepreneurs shape economic destiny of nations by creating wealth and employment, offering products and services, generating taxes for Governments. That is why entrepreneurship has closely been linked to economic growth. Entrepreneurs convert ideas into economic opportunities through innovations which are considered to be major source of competitiveness in an increasingly globalizing world economy. Therefore, most Governments in the world strive to augment supply of competent and globally competitive entrepreneurs in their respective countries. Without a strong entrepreneurial community the developing countries will not prosper despite their rich resource endowments [37].

\section{Objectives of the Study}

The people of North East Region of India including the tribal communities of Arunachal Pradesh inherited rich tradition of craftsmanship and are very adept at crafts such as weaving, woodcarving, carpet weaving, cane and bamboo works, smithy works, etc. Although they possess a strong background of artisanship the society has not evaluated to embrace entrepreneurship. Due to this the economy and the youths of this region could not develop and there has been a visible regional disparity comparing to the mainland of India. This situation has led to a need to understand the role of entrepreneurship for development of this region as promotion of entrepreneurship may contribute to self-employment, employment generation, poverty alleviation, women empowerment etc. in this backdrop, the objectives of the study are:

1. To access the present scenario of entrepreneurship in the region.

2. To evaluate the relevance of entrepreneurship in the socio-economic development with illustration from real life examples of the successful entrepreneurial initiatives.

3. To motivate youths to opt for entrepreneurship as career option.

Hypotheses: The hypotheses framed for this study are as follows:

1. The youths of NER including that of A.P. have the 
potential to be successful entrepreneurs.

2. The initiative Social Entrepreneurship has started showing emergence in NER.

3. Due to so many challenges including lack of adequate supports and absence of ecosystem entrepreneurship is yet to be popular in NER as well as in A.P.

4. In the age of globalisation many problems of NER can be solved through promoting entrepreneurship.

\section{Literature Review}

We start with recent definition of entrepreneurship put forward by Bula which says the classical and neo-classical theorists have labored in trying to define entrepreneurship, but there is no single definition of Entrepreneurship. It all depends on the focus of the one defining it and from which perspective one looks at it. Some researchers look at entrepreneurship from the economics view, sociology and psychology, others look at it from the management perspective, while others look at it from the social perspective. Entrepreneurship is a therefore a multidimensional concept (Bula, 2012a) [2].

An entrepreneur is an owner or manager of a business enterprise. He makes money through risk and initiatives. The term was originally a loanword from French first used in 1723 , and was defined by the Irish-French economist Richard Cantillon (1680 - 1734) [14]. Today the term entrepreneur implies qualities of leadership, initiative, and innovation in new venture design. Economist Robert Reich has called team-building, leadership, and management ability are the essential qualities for the entrepreneur. Historically the study of entrepreneurship reaches back to the work in the late 17th and early 18th centuries of Richard Cantillon and Adam Smith, which was foundational to classical economics. Joseph A. Schumpeter also did pioneering work on entrepreneurship. Schumpeter's concept of the entrepreneur was widely recognized. His major work The Theory of Economic Development in German in 1911, and later on an English version of it came out in 1934. To him the human agent are at the centre of the process of economic development [12].

Entrepreneur in English is a term applied to a person who is willing to help launch a new venture or enterprise and accept full responsibility for the outcome. Jean-Baptiste Say, a French economist, is believed to have coined the word "entrepreneur" in the 19th century - he defined an entrepreneur as "one who undertakes an enterprise, especially a contractor, acting as intermediary between capital and labour". A broader definition by Say is, "The entrepreneur shifts economic resources out of lower and into higher productivity and greater yield." The term "entrepreneurship" was coined around the 1920s, while the loan from French of the word entrepreneur dates to the 1850s [14].

The entrepreneurship development in India was initiated following the Kakinada Experiment (1964) by David McClelland (1917 - 1998). The National Science \& Technology Entrepreneurship Development Board (NSTEDB), established in 1982 by the Government of India under the aegis of Department of Science \& Technology, is an institutional mechanism to help promote knowledge driven and technology intensive enterprises. Entrepreneurship Development Centre (EDC) scheme of India aims to set up a cell where the skills required becoming an Entrepreneur is developed [37].

India has been growing at a relatively high rate, envisioned to be the largest economy in the world by 2050 . Unlike most of the developed economies, India is a young country with about 63 per cent population currently being in the working age group ( $15-59$ years). This is a plus factor as the studies say the nascent entrepreneurship prevalence rates are highest in the 25-34 age-groups (EDII). The country has a demographic dividend to en-cash however it could prove to be its impediment if she fails to engage her youths in creative pursuits. In this context we may concentrate our focus with respect to North East Region of India in general and the state of Arunachal Pradesh in particular.

Again another important aspect is Skill Development \& Entrepreneurship. In fact, Skill development and entrepreneurship cannot be viewed in isolation. For Skills Strategy will be successful if it commensurate with job creations. This has to happen in the primary, secondary and in tertiary sectors as well. This demands a robust MSME sector. India's MSMEs contribute to $17 \%$ of GDP as compared to $85 \%$ in Taiwan, $60 \%$ in China and $50 \%$ in Singapore.

Globally India is one of the youngest nations having more than $54 \%$ of its total population below 25 years of age. The average age of her population will be 29 years by 2020 as against 40 years in USA, 46 years in Europe and 47 years in Japan. During the next 20 years the labour force in the industrialized world is expected to decline by $4 \%$, while in India it will increase by $32 \%$. This poses formidable challenge and huge opportunity. Evidently this demographic dividend will last for next 25 years. To reap benefits India has to equip the workforce with employable skills. Skills and knowledge are driving forces of economy. However India is late to get engaged with this important aspect. This is evident as the first Industrial Policy was notified in 1956, Science \& Technology Policy in 1958, Housing Policy in 1988 and National Labour Policy in 1966 whereas the National Policy on Skill Development was notified in 2009 and reviewed as the National Policy for Skill Development \& Entrepreneurship in 2015[36].

India has $4.69 \%$ of the total workforce who undergone formal skill training as compared to $68 \%$ in UK, $75 \%$ in Germany, $52 \%$ in USA, $80 \%$ in Japan and $96 \%$ in South Korea. As per a skill gap study of National Skill Development Corporation (NSDC) over 2010-14 indicates that there is an additional net incremental requirement of 
109.73 million skilled manpower by 2022 in twenty four key sectors (2011-12, NSSO). Also, the number of people who enter the work force age group every year is estimated to be 26.14 million. In that analogy, our workforce needs to be mapped through recognition of existing skills and then provide them with necessary skilling, re-skilling and up-skilling to increase productivity and provide a livelihood pathway. We need to increase women's participation in the country's labour force. Census data shows a continuing fall in labour force participation rate of women from $33.3 \%$ to $26.5 \%$ in rural areas and from $17.8 \%$ to $15.5 \%$ in urban areas between 2004 and 2011[31]. In this context, the Arunachal Pradesh has higher rate of women participation a silver lining indeed. As per a study the success ratio of female and male entrepreneurs is 63:37 in terms of various parameters of establishing micro enterprises (Deb Sukamal, 2014, author). The State is also rich in traditional skill. Also an UN finding say India's GDP will leap frog by another $4.2 \%$ if her women can contribute their full potential to the economy.

\section{Methodology}

Selection of method of research depends upon the nature of the problem in hand. The present study is mainly based on secondary sources of data although in some cases primary data source is also explored. We have collected the secondary data from the published books, journals, Government reports, newspapers to facilitate the study. For secondary data, cross-verification is made wherever possible between various institutional statistics. While secondary data are used, inferences and explanations were made independently. Facts and information were also gathered through informal talks with officials and other individuals as well.

Universe of the Study: The universe of the study is North East Region of India with focus on A.P., a NER State. We discuss one by one.

North East Region of India (NER): In little harsh words, people say the NER is the "Black Box" of India's economic policy. The North-Eastern Region Vision - 2020 (2008) describes the Region as "a rainbow country extraordinarily diverse and colourful, mysterious when seen through parted clouds [33]. NER consists of the States of Assam, Arunachal Pradesh, Manipur, Meghalaya, Mizoram, Nagaland, Tripura and Sikkim, potentially one of the richest geographical units of the country. Flanked by hills and with the mighty river Brahmaputra slashing a central path between its north and south, the NER is potentially one of the richest geographical units of India. It is a land where tea is an industry, handicrafts a major occupation. The NER is one of the most bio-diverse regions in the world.
The isolation of the NER began earlier as a result of British imperialism, when the Region was cut-off from its traditional trading partners (Bhutan, Myanmar \& Indo-China). The western side of the NER is connected to the eastern part of the Indian subcontinent by a narrow land corridor, referred to as the Siliguri Neck with an average width of $21 \mathrm{~km}$ to $40 \mathrm{~km}$. The partition and creation of erstwhile East Pakistan dislocated traditional trade routes and markets for NER leading to low accessibility to market and source of raw material. As a consequence it continued to remain industrially backward. Sadly many of her facts do not seem to exist because they are ignored. Village Industries, especially the colourful traditional textiles is a dominant activity of the NER. Gandhiji said "... millions to spin their yarn in their own homes as today they cook their food in their homes". It is said that many of the North Eastern States were created to fulfill the ethnic, political and cultural aspirations of the people compromising the financial viability. The major portion of the receipts for most of these states comes from the Centre, tax revenues are negligible and the Non-Plan revenue expenditure is high. The primary sector economy due to small land-holding, high cost of inputs and low yield rate is not lucrative. Creation of employment in public organisations already reached the point of saturation with very high public servants to population ratio. Jobs in private and service sector are inadequate, although there has been a little improvement in recent times. There has been a mismatch in jobs creations and job seekers. Population per Small Scale Industries (SSI) in NER is 2.33 times greater than that of India and the per capita small industrial production stands at only $27.44 \%$ of the figure for the country as a whole. The technological status is low. The economy of the region has got its definite identity due to its peculiar physical, economic and socio-cultural characteristics. This region covers an area of 2.62 Lakh sq. $\mathrm{km}$. It accounts for $7.9 \%$ of country's total geographical area. With a total population of 45,587,982 (2011), it accounts for $3.77 \%$ of total population of India. About $98 \%$ of border of the NER forms international boundaries $(4500 \mathrm{~km})$ [25]. Throughout its history the NER is known to have been an important physical and cultural bridge between India and Southeast Asia, an important focus area for archaeology. The proportion of tribal population ranges from 19.3 per cent in Assam to 94.5 per cent in Mizoram. NER is largely rural with over 70 per cent of the population living in the country-side. It has over 160 Scheduled Tribes and over 400 other Sub-tribal communities and groups. The region with over 220 ethnic groups and equal number of dialects makes it hugely diverse. India's Look East Policy, recently emphasized to act upon more seriously, has emerged as an alternative vintage point of development paradigm for NER. Considering its immense export potential together with its unique location, makes an ideal case to be declared a Special Economic Zone (SEZ) [32]. 
Table 1. Basic Information of NER

\begin{tabular}{|c|c|c|c|c|c|}
\hline Population - & \multicolumn{5}{|c|}{$38,857,769(2001)$ and $45,587,982(2011)$} \\
\hline Decennial growth & $17.32 ;$ & Area - & $262,230 \mathrm{~km}^{2} ;$ & Population density - & $148 / \mathrm{km}^{2}$ \\
\hline
\end{tabular}

Source: Census of India 2001 and 2011

Table 2. State wise Basic Information of North Eastern States

\begin{tabular}{|c|c|c|c|c|c|c|c|c|}
\hline State & A.P. & Assam & Manipur & Meghalaya & Mizoram & Nagaland & Sikkim & Tripura \\
\hline Capital & Itanagar & Dispur & Imphal & Shillong & Aizawl & Kohima & Gangtok & Agartala \\
\hline Largest city & Itanagar & Guwahati & Imphal & Shillong & Aizawl & Dimapur & Gangtok & Agartala \\
\hline Districts & 17 & 27 & 9 & 7 & 8 & 11 & 4 & 4 \\
\hline Statehood on & 20.2 .1987 & 15.8 .1947 & 21.1 .1972 & 21.1 .1972 & 20.2 .1987 & 1.12 .1963 & 16.5 .1975 & 21.1 .1972 \\
\hline Area Sq Km. & 83,743 & 78,550 & 22,347 & 22,720 & 21,081 & 16,579 & 7,096 & $10,491.69$ \\
\hline $\begin{array}{c}\text { Population } \\
(2011\end{array}$ & $1,382,611$ & $\begin{array}{c}31,169,27 \\
\text { Census) }\end{array}$ & $2,721,756$ & $2,964,007$ & $1,091,014$ & $1,980,602$ & $6,07,688$ & $\begin{array}{c}3,671, \\
032\end{array}$ \\
\hline $\begin{array}{c}\text { Density of } \\
\text { population }\end{array}$ & $16.5 / \mathrm{Sq}$ & $\begin{array}{c}396.8 / \mathrm{Sq} \\
\mathrm{Km}\end{array}$ & $\begin{array}{c}121.8 / \mathrm{Sq} \\
\mathrm{Km}\end{array}$ & $\begin{array}{c}130.5 / \mathrm{Sq} \\
\mathrm{Km}\end{array}$ & $\begin{array}{c}51.8 / \mathrm{Sq} \\
\mathrm{Km}\end{array}$ & $\begin{array}{c}119 / \mathrm{Sq} \\
\mathrm{Km}\end{array}$ & $\begin{array}{c}85.6 / \mathrm{Sq} \\
\mathrm{Km}\end{array}$ & $\begin{array}{c}349.9 / \mathrm{Sq} \\
\mathrm{Km}\end{array}$ \\
\hline Literacy rate & $66.95 \%$ & $76.3 \%$ & $79.85 \%$ & $72.1 \%$ & $89.9 \%$ & $63.7 \%$ & $76.6 \%$ & $87.75 \%$ \\
\hline
\end{tabular}

Source: Census of India, 2011;

Arunachal Pradesh (A.P.): We now focus our discussion on Arunachal Pradesh which is a tribal State of India, where she has about 3.64 Lakh persons in the age bracket of 15-29 years (Census, 2011). Most of this population chunk is either in education or looking for employment. According to a Skill-gap-study in the North East Region conducted by ICRA Management Consulting Services (IMaCS) in 2011, the State will have a man power supply of 7.50 Lakh between 2011- 21 while the demand for internal growth will be around 1.47 Lakh leaving a youth population of additional $6.03 \mathrm{Lakh}$ in next 4 years. We need to appreciate it as an opportunity not from the perspective of problem. The challenge is to harness these youths to productive works, the most important task at this deciding moment of her development [38].

A.P. could be briefly described as the thirteenth geographically largest frontier State of India covering an area of $83,743 \mathrm{sq} \mathrm{km}$ in hilly terrain of Eastern Himalayas having population of 13,82,611 persons has 3,863 villages, living $77.33 \%$ in rural areas (2011 Census). The territory was called "Terra Incognita" or No Man's Land (Begi, 2008) till the beginning of the twentieth century. The Government of India's efforts mainly aimed at integrating the territory into the mainstream of national consciousness and economic development. Thus, the agenda of "Entrepreneurship Development" is yet to get needed importance in the State.

If we relook at the policy inception in A.P. for industrial development we find that a start was given in 1952 through Policy of Craft Promotion by creating the Department of Cottage Industries Development. Her crafts are rich in words of Gunnar Myrdal "Crafts and Small-Scale Enterprises have deep and well-established roots in South Asia's indigenous economic development (Asian Drama)". We know India's first tribal stamp originated in North East
Frontier Agency (NEFA) based on a photograph of a Konyak (a tribe) woman in weaving photograph of a Konyak woman captured in 1947 by Verrier which was issued on Republic Day of India in 1955. In understanding the complexity of development of the State, we find the task of nation building started belatedly here and adequate importance was not accorded in promotion of her treasure trove of arts and crafts. If we fail to be the herald of development of her villages, the ongoing trend of migration of rural youths to towns cannot be clutched. Migration is a function of labour reallocation in response to market demands. It is also a reflection of rural poverty. In the words scholar Dipankar Gupta, "the Indian villages have started disappearing" a trend rapidly spreading its contagion in youth minds. So the rural areas are to be revitalized else our capital and small towns will be in distress with lack of civic amenities. This is in tune with John W Keller's (2000) findings on rural - urban migration issue [22].

The answer is to innovate, to encourage Reverse Migration. Our youths with new ideas and entrepreneurial zeal move towards "Rural Arunachal" to tap the vast unexplored resources and the talents to wealth. A.P. is bestowed with the wealth of natural resources like forest, minerals and traditional tribal knowledge about the natural eco-system, medicinal plants, forest eco-system etc. Then why should her villages continue to remain under-developed and face problems of poverty, malnutrition, low literacy and poor health. These mammoth problems can only be solved when inspired individuals challenge the status quo with their entrepreneurial zeal and spirit of innovation and develop solutions based on her core strengths. The take away is, inspire, nurture and promote the spirit of entrepreneurship.

Data analysis: Most of the people in rural areas of NER 
are engaged in primary sector. As a result marginal productivity of labour is almost zero or even negative. The increase in youth population and the literate persons in general and the educated persons in particular amidst the limited openings of jobs suitable with their educational attainment itself originated the problem of educated youth unemployment. This phenomenon resulted people to migrate to other region in search of job. The region's work force participation rates have declined for the youth due to the increase in search of higher education and salaried job. The increase in the share of employment in tertiary sector partially explains the situation. Both for the general and educated youth unemployment problems are more severe in NER compared to the national average because of the higher prevalence of unemployment rates in the region. Population dynamics has two basic components, dynamics through natural processes and dynamics through induced processes. Individual state focussed researches testify the above statement (Panda, 1988, Rai and Goel, 1984). As regards to natural growth rate of population during the period 1971 - 81, all the states in the region have registered higher growth rate than the rate for the whole country (Butola, Undated P.32). The same trend continued during the period 1981-91. The increasing population pressure has given rise to linkages between quality of life, population dynamics and environmental degradation. During this period, average annual exponential growth rate for the region ranges between 2.12\% (Assam) and 4.5\% (Nagaland) against the national rate of only $2.11 \%$. There has been remarkable alternation in the demographic characteristics of the region. NER have just 25 out of a total of 543 seats in the Lok Sabha/ India's Parliament (4.6\%) for its small electorate.

Despite massive development efforts undertaken by the Governments through a plethora of developmental schemes, the persistent problem of mass poverty, malignant growth of unemployed youth and large scale migration of people to urban areas has still been going faster nullifying these efforts. This remains a fact to the NER too. There has been enough expenditures are incurred by the North Eastern States in the name of administration and development but in true sense only little investment are being made for the real and sustainable development.

One prescription may well work for promotion of the NER is Cluster Development for MSE. There are natural clusters in the NER, e.g. Cane Mat Weaving (Sheetal Pati) of Barak Valley (Assam), Bamboo Crafts of Tripura, Brass Metal Clusters, Silk and weaving, bee keeping clusters of Assam, to name a few. These natural clusters if supported effectively in modern lines are bound to create entrepreneurship, new markets and a vista of progress of NER. The Abid Hussian Committee Report on SSI cluster (1997) outlined the dimension of cluster. The Cluster topology distinguished the clusters as High Tech Cluster, Traditional Manufacturing Cluster and Micro Enterprises Cluster. The report say India has around 6600 goods based clusters out of which 6200 are low-tech micro enterprises cluster. It would remain a fact that a considerable number out of 6200 cluster are in dormant status in NER.

Cluster development is considered as an effective tool for fostering economic growth and innovation. Industrial clusters serve as one of the most effective mechanisms for spurring income and employment growth especially by micro, small, and medium enterprises (MSME). Michel Porter, father of industrial cluster concept, defines a cluster as a 'geographically proximate group of interconnected companies, suppliers, service providers and associated institutions in a particular field, linked by externalities of various types'. So, the role of the government would be to identify their growth barriers and act as true facilitator. As said the NER may create promising and export potential clusters ushering new era of entrepreneurial culture. Cluster with Common Facility Centre (CFC) and developed infrastructures, connectivity provide a competitive and mutually beneficial environment to the enterprises with less investment. Naturally-grown cluster is a phenomenon in common for the NER, if adequate supports are extended the NER will be benefitted considerably. A study in context of neighbouring country of Bangladesh says Cluster development should be one of the top priority issues for the government to generate employment, create self-employment through entrepreneurship development, revenue earnings, reduce poverty and finally increase GDP growth (http://www.thefinancialexpress-bd.com/2016/02/02/1368 9) [16].

The concept of Social Entrepreneurship is slowly spreading its root in the NER. For example in $2016 \mathrm{Mr}$. Neichute Doulo [27] was declared as the Social Entrepreneur of the year (SEOP). Mr. Doulo is the CEO and coordinator of Entrepreneurs Associate (EA), Kohima. The SEOP is an annual award started by the Schwab Foundation for Social Entrepreneurship in partnership with Jubilant Bhartia Foundation. The contenders for the award "are evaluated on key parameters of innovation, sustainability, scalability, reach and impact." Mr. Doulo described the award as a great accomplishment for Nagaland and the NER. He said this will have a great and positive impact on the region. He added, "I believe that this will also help the NE region to become an asset to the country and not to be seen as a liability and a region of problems but of opportunities and solutions." Mr. Doulo as one of the main architects of EA, an organization dedicated to youth empowerment through promotion of entrepreneurship for the last 17 years, has been instrumental in shaping the way Nagas view entrepreneurship. His work through EA has impacted thousands of Naga youths over the years - linking, guiding and acting as business facilitators. As a student, he sold newspapers before working as a teacher (Economics), which he subsequently quit in 2000 to immerse fulltime into his current work. In 2001, he received the International 
Ashoka Fellow and in the state, he was a recipient of the Naga Mothers Association Award. He contributed to social change (Express News, Dimapur, October 6, 2016).

We now narrate another case study. It is of Dr. Borah whose life story has seen three interesting metamorphoses one that was an arduous journey of a marginal's farmer's son to become a doctor, second when doctor becomes a successful healthcare entrepreneur and third, the transformation of a successful healthcare entrepreneur becomes a social entrepreneur [8].

In his career that spans for more than 40 years, he built a business empire that presently includes GNRC Hospital Dispur, Asian Institute of Nursing Education, Medishop Retail Chain, GNRC Six-mile and GNRC Institute of Medical Sciences, a 1200-bedded facility which commenced operations in early 2014 at North Guwahati. Moreover, GNRC's initiative was also recognized by the World Bank Group (WBG), through its India Development Marketplace (IDM) initiative, to receive a grant of $\$ 150,000$ to help scale its operating model.

Dr. Borah could extend his services to Assam and the NER as well as the neighbouring South East Asian countries of Nepal, Bhutan, Bangladesh and Myanmar, where super specialty, tertiary healthcare facilities are lacking. The GNRC Medical provides affordable access to quality healthcare services through a low cost model. The GNRC also signed a Memorandum of Understanding with Mumbai-based Pawan Hans for an air ambulance and medical outreach programme using helicopters to remote areas of NER. This successful healthcare entrepreneur has built a formidable legacy with a radical change in the healthcare system. From his experience of four decades in the healthcare industry, he has come up with revolutionary ideas and implemented them. His other projects have become success stories of their own and have created the pathway for others. Examples include the Medireach project, Medishop (the first chain of retail drug stores that was launched in North-East India stocking both medicines and FMCG products), executive health cards, etc. (gnrchospitals.com/) [8].

We would also like to share a story of Social Entrepreneur that rooted to the State of A.P. This is the story of Oju Welfare Association and its founding Chairperson Binny Yanga. It is also a case of successful women entrepreneur. Binny Yanga [19] registered her adult education and nursery centre in 1979. She founded a registered society in 1988, under the name Oju Welfare Association (OWA). The centre has grown over the years into an organization with a number of divisions, each catering to a specified purpose. OWA runs a free educational institution in, a children's home, home to orphaned children, Short Stay Home, a temporary place of residence with a capacity to house 45 destitute girls or women, a working women's hostel, a family counselling centre and a women's help line. They run a girl's school, a secondary school and a vocational training centre. OWA also hosts the Government of India's State Resource Centre.

Binny Yanga was born on 7 July 1958 in the Indian state of Arunachal Pradesh to late Binny Jaipu, a former political assistant at Lower Subansiri district. She is known for her efforts for the revival of traditional handlooms. She did her education at Banasthali Vidyapith, Rajasthan. After her studies, she started her career as a teacher. During this period, she set up an adult education and nursery centre and, later, a shelter home for destitute girls. In 1987, Yanga joined Arunachal Police Force, when the first batch of women officers was inducted in 1987. One year later she resigned to enter social service on a full-time basis.

During her life time Yanga used to organize social awareness campaigns and seminars on health and other issues. She worked for the promotion of traditional crafts of A.P. To support marketing the products of rural artisans she founded a Multi-purpose Co-operative Society. (https://en.wikipedia.org/wiki/Binny_Yanga). OWA is one of the pioneering Social Enterprise, a philanthropic organisation of the state. Ms Ratan Anya is the present Chairperson of the OWA (owaap.org.in/) [28].

We illustrate more case studies that would inspire and sensitize the Vision of the youths. Also by sharing more real life stories of innovative entrepreneurs, we may give this paper a guided conclusion as the youths has to bridge developmental partnership with innovators. Everyday be it globally or within the Indian subcontinent new ideas, new institutions are emerging. The need is to set an interface with these people and their institutions. The Government essentially has to play the role of true facilitators.

I met Mr. Tenzing Bodosa recently (in November, 2017) in a Global Tribal Entrepreneur Summit, where he was honoured as a tribal entrepreneur. He is Assam's first Organic Tea Farmer. He owns the world's first elephant friendly tea farms. He says if you respect nature, nature will respect you. His two farms in Bodoland, Assam have been certified as the world's first elephant-friendly farms.

Here is the story of Mr. Bodosa [14, 27]. There was a time when Tenzing did not want to become a farmer like his father and grandfather. He dropped school after class VI, left home when he was 10 to work and help his widowed mother who was looking after their 2 hectare ancestral farm. After doing odd jobs for few years he joined a Malaysian Construction Company where he learnt to drive, repair machinery, work on internet and English. In 2006 at the age of 19 he returned home, started looking for alternative livelihood. He conceived an idea of organic tea farming but everyone told him tea could not be grown organically. Tenzing did his research online, came to know about $\mathrm{L}$. Narayan Reddy, Bengaluru who was doing it organically. Although Reddy guided him he was not fully satisfied. In 2007 a Canadian NGO, Fertile Ground gave him trainings enabling him to start his organic farm. Tenzing is the only farmer among 12000 who grows organic tea. He owns his processing unit and sells tea in Canada, German, US and 
UK. Today he has 25 Acre of land doing farming of various paddy, fruits and vegetables all organically. His yearly turnover from the tea plantation on just 7.5 Acre of land is around INR 60 - 70 lakh. He has employed 50 persons.

Interesting part of his farm is the buffer zone, the area at the end of his farm from where the jungle begins at the Bhutan border. He has spared a part of his land contiguous to, has not cut down any tree or set any fire there, instead planted bamboo on which the wild elephants feed. He has not put any barrier, so wild animal freely move in his farm. At time one can see 70-80 elephants, hornbills, wild pigs, deer, peacocks and variety of birds. This has added to the attractions to visitors, tea buyers; the foreign tourists come to see it. (https://bkbro.sarahah.com). He can be a real source of inspiration for our youths.

\section{Some illustration of possibilities for entrepreneurs in various areas:}

Organic farming, Arunachal Pradesh may become a model: Organic farming has always been the most natural method of growing crops using natural fertilizers and manures. Following the green revolution in the early 1960s, the Indian agriculture sector gradually witnessed a shift to synthetic fertilizers. Though this ensured faster and bountiful production, the crops became highly contaminated posing threat to general well-being. In a reverse shift, the country started adopting organic farming during the late 90s'. In 2004 India introduced the National Project on Organic Farming. Within 10 years the amount of certified organic land (land free of chemical residue) increased from 42,000 hectares to 4.72 million hectares. In 2005, as per Government of India figures, approximately 190,000 acres $(77,000$ hectares) were under organic cultivation. Organic India is now one of the biggest players in the business and has seen its revenue rise from INR 25 crore in 2008 to INR 175 crore in 2013. According to reports by Assocham and TechSci Research, the organic food market in India is estimated to be over US\$0.50 billion. It is further projected to reaching up to US\$1.36 billion within the next four years. Overall, the organic foods segment in the country has witnessed an estimated 25 per cent to 30 per cent growth [33]. While once consuming organic food was perceived to be a trend, now it has become essential, considering its medicinal benefits. The consumers are becoming increasingly aware of what they are consuming and how it impacts their health in the long term. They are relying on organic food as the 21 st century medicine to beat lifestyle diseases like cancer, diabetes and obesity.

The Sresta Natural Bio Products is one of the leading organic processors and suppliers. In the backdrop of excessive and harmful usage of pesticides began the story of Sresta. In 1992, Founder Raj Seelam realized how investment in pesticides and synthetic fertilizers were affecting the sustainability of farmers' lives and standard of living. He set out on the journey to set up the firm in 2004.
Today over 50,000 farmers cultivate 2, 50,000 acres across 15 states in India, covering varied agro-climatic zones. They aim to reach 500,000 acres by 2020 .

Organic farming could be fit case for the State. Organic cultivation, enhanced productions and value addition locally adopting appropriate technology in lieu of Jhum or through scientific Jhum Cultivation may be a right approach for her to join Make India Mission. One needs to know, among the 100 most climate-sensitive districts in India 16 are in NER of which 2 are in A.P. (West Kameng and East Siang districts). Since link between poverty and environmental degradation is very strong we need to reorient our developmental programmes accordingly (read full paper of Dr. Sukamal Deb on line, 2015) [5].

Bamboo Based Activities: We start with a story published in the Indian Express on 25-11-2017 [25] captioned Bamboo cycles may soon grace a cycle track. The cycles are made by members of 10 agricultural families based near Pune, who are involved in bamboo plantation. It weighs only 2 kilo gram but is sturdy and easy to ride. The cycles are designed by Bamboo India, a Pune based company. Yogesh Shinde, founder of Bamboo India, said concerns about the increasing use of plastic, and its harmful effects on the planet prompted him to introduce cycles made of bamboo. The cycle, which costs INR 35,000 , has an online customer base of over 9,000 people in India is also becoming increasingly popular in Netherlands, US and Europe. There are 136 species of bamboo and they are working on developing cycles with newer species.

Rural Technology: A Polish Proverb says, "If the farmer is poor then so is the whole country". We know one quarter of the world's poor, almost 300 million, live in India. The IT sector accounts for almost 4 per cent of GDP, but employs only a million. Rural Technology can help dramatically reduce the prevalence and severity of many developmental problems. It can help improve the quality of life, especially for the poor and disadvantaged, by permitting more and better services, transforming economic activity and reducing inequalities. It gives solutions that are affordable, sustainable and acceptable to the people. (www.rtbi.in/Ashok/14.pdf).

There are organizations working for innovating Rural Technology. We discuss the endeavour of Vigyan Ashram [47]. It is a centre of Indian Institute of Education (IIE), Pune. A scientist turned educationalist Late Dr. S. S. Kalbag started Vigyan Ashram in 1983 to find out solution to the problems in education. They offer Diploma in Rural Technology course for youth who want to start an enterprise. (Read success stories at vigyanashramalumni.wordpress.com, ruralstartup.wordpress.com, vigyanashramdbrt.wordpress.com, vigyanashram.wordpress.com).

Vigyan Ashram works on Rural Technologies like vaccination of animal, drip irrigation, nursery technique, 
agriculture tools, watershed development, sanitation and food preservation. These innovations may have far reaching impact in the developmental efforts of A.P. if applied.

Similar is the case of STARS (Skill Training for Advancement in Rural Societies) Forum [45] established in 2010 with objectives of constituting a common platform for NGOs and individuals working in the area of knowledge transfer of relevant marketable / vocational skills in rural and tribal areas. This is for mutual support and to advance this field by providing a forum to dialog, problem solving and sharing and evolution of best practices and innovative approaches through practical, relevant and cost effective way (www.starforum.org). The State and her youths need exposure and eagerness of networking with these organisations in her pursuit of development.

\section{Findings and Recommendations}

The objectives of the study were to access the present scenario of entrepreneurship in NER, to understand the relevance of entrepreneurship in the socio-economic development taking in considerations practical examples of the successful entrepreneurial initiatives and more importantly motivate the youths. After doing this study primarily based on secondary data we feel that the objectives have been accomplished.

We started with the hypotheses that the youths of the study area have the potential to be successful entrepreneurs; the initiative of social entrepreneurship has been emerging in NER. Our hypotheses also that there has been lack supports and absence of ecosystem in the region including A.P. for promotion of entrepreneurship and our hypothesis also based on the fact that in the age of globalisation many socio-economic problems can be addressed by promoting entrepreneurship. The Hypotheses appears to have got satisfied.

In the course of literature review that grounded and shaped our study enables to identify the gaps. We implicitly illustrated that the nation build works started belatedly in this region of India. The research problem that was targeted in the course of study is in well matching to the ground realities although we ended up with a positive note that we not only to looking beyond but within too in our sincere pursuit to promote entrepreneurship.

We could established the fact that the base of entrepreneurial supply has historically been rather narrow, confined by and large to a few castes and communities, leaving out a large section of society consisting particularly of women, scheduled castes \& scheduled tribes (SC \& ST), minorities, artisans, etc., under-represented. This remains a truth so far the NER is concerned. We explained that the supply of entrepreneur has also been regionally imbalanced, leaving the North Eastern Region of India under-represented. This is verified from the data of the fourth Census of Micro, Small \& Medium Enterprises (MSME). The census says women accounts 7.36\% ownership (Global average $7.72 \%$ ), SC \& ST $11 \%$ and the NER $3.48 \%$. The ownership is confined to micro enterprises [39]. These are our findings based on the literature reviewed.

We cheered us through the stories, gathered from the core of reality. It brings a charming and exciting experience of entrepreneurship that germinates in the NER in transforming the image of less developed part of India. We know a social entrepreneur is an individual who recognise a social problem and use entrepreneurial principles to organize, create, and manage a venture to make social change. He is an individual with innovative solution to society's most pressing and daunting social problems. He is ambitious and persistent, tackling major social issues and offering new ideas for wide social change. He is different from business entrepreneur in the sense that he measures his performance in terms of impact made on society. He brings in simple idea that lead to job creation, innovative new technologies and the establishment of lasting institutions. We felt the charm of these awesome attributes among few entrepreneurs of NER too when we studied their cases. We record with confidence that it is not fact that youths of A.P. are not innovative. Among others just one is Mr. Mihin Doilang of Ziro, Lower Subansiri district [Figure 13] designed a cardamom drier, a useful innovation. We need to celebrate their entrepreneurship and their stories to be told to the world beyond the confined horizon of NER and the state of Arunachal Pradesh.

Also, inter alia, we laid our emphasis that the core issue in the policy framework of the Government towards the economic development should be ingrained to the motive to inspire, nurture and promote the spirit of entrepreneurship for "there is no country that has high levels of entrepreneurship and low levels of economic growth (Reynolds et al., 2002)". This remains our most important recommendations as an outcome of the study among others. A study in Indian context on the basis of a cross section of data for 17 Indian States found a positive impact of the index of entrepreneurship on per capita income. In fact, underdevelopment is not because of the lack of natural resources but because of the absence or inadequate supply of entrepreneurs. If only natural resources were the key determinant of economic growth, the entire African continent or Latin America or most of Asia would have been developed. Within India, States like Assam, Bihar, Madhya Pradesh, Orissa, even Arunachal Pradesh would have been leading the growth trajectory of the country. In fact, economic growth is the outcome of entrepreneurial endeavours.

The problem of unemployment cannot be tackled by creating more jobs in the public sector; the answer is harnessing entrepreneurship and promotion of micro and 
small enterprises (MSE). So the policy of A.P. at the inception of her developmental pursuit, say, around 35 years back, needs a paradigm shift. A.P. need a paradigm shift in redefining the inclusive development of her less visible areas of 3863 villages spreading over $83,743 \mathrm{sq} . \mathrm{km}$. area.

There has been an urgent need to ensure that the young minds find the right knowledge and the right atmosphere to dream and the right preparation to achieve their dreams. The present century has thrown up unfamiliar challenges, the kind that mankind has not seen yet, the pace of change has been fast. So the youths they need employment to face the challenges. According to statistical data during the period of 2005 to 2010 only 2.7 million net additional jobs were created in India, even though the country has been facing the increasing problems of un-employability. To overcome this she needs more entrepreneurs, which are the real backbone of Indian economy. Skill development and creating job opportunities go hand in hand to enhance the country economically and technically. Developing entrepreneurship opportunities meet the required demand of economic landscape of India. There is a necessity to develop and strengthen entrepreneurial quality, motivate it and give all the support to withstand firmly for the youth aspirations.

\section{Conclusions}

We conclude that the pathfinders are the entrepreneurs, they are agents of development. So, panacea is promotion of entrepreneurship, the Rural Entrepreneurship, Agri-Preneurship, Women-Preneurship, Tourism Entrepreneurship, and Social Entrepreneurship. This will give momentum to the State's or NER's developmental agenda. An ecosystem need to prevail to groom the youths with the relevant skills, inspire motivation, bring innovation, the appropriate technology (not always the hi-tech), relooking at the resources with wisdom, sensitize on sustainability. The egalitarian tribal social order and dignity of labour were their assets once need to be restored and preserved.

The call deserves to be echoed louder and louder at her vast horizon. If Entrepreneurship is her vision today way needs to be paved to translate the 'vision - in - to - realty'. According to World Travel and Tourism Council, "India has potential to become number one tourist destination in the world with the demand growing at $10 \%$ per annum". The Dawn Lit State of A.P. should then inquisitively see her silver-lining there.

\section{Appendix}

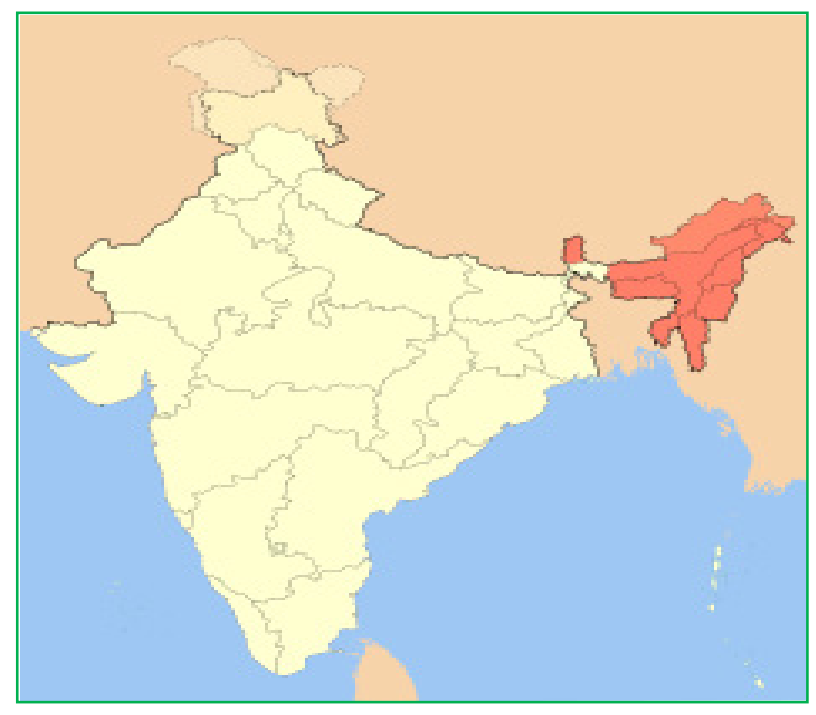

Figure 1. Map of India

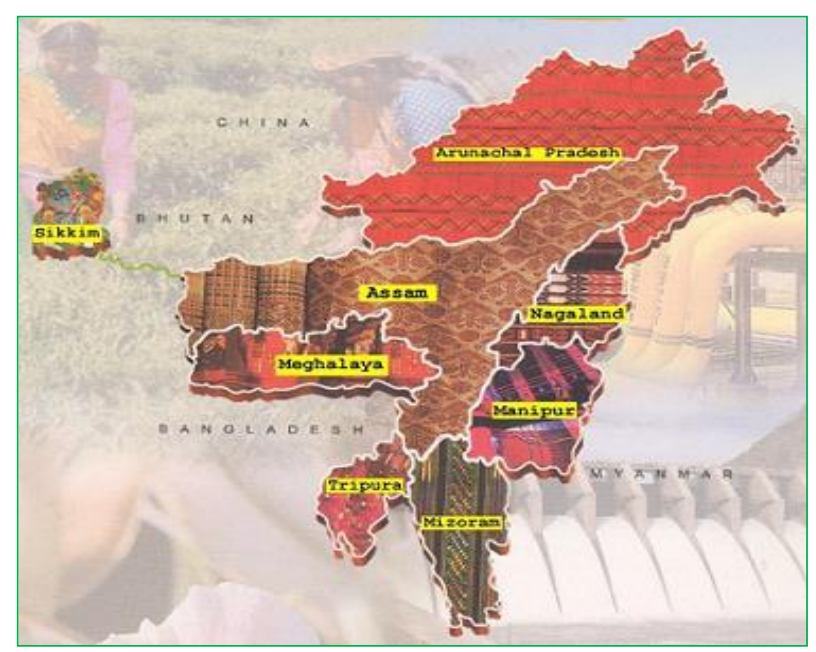

Figure 2. Map North-East States

Story of Assam's First Organic Tea Farmer Mr Tenzing Bodosa:-

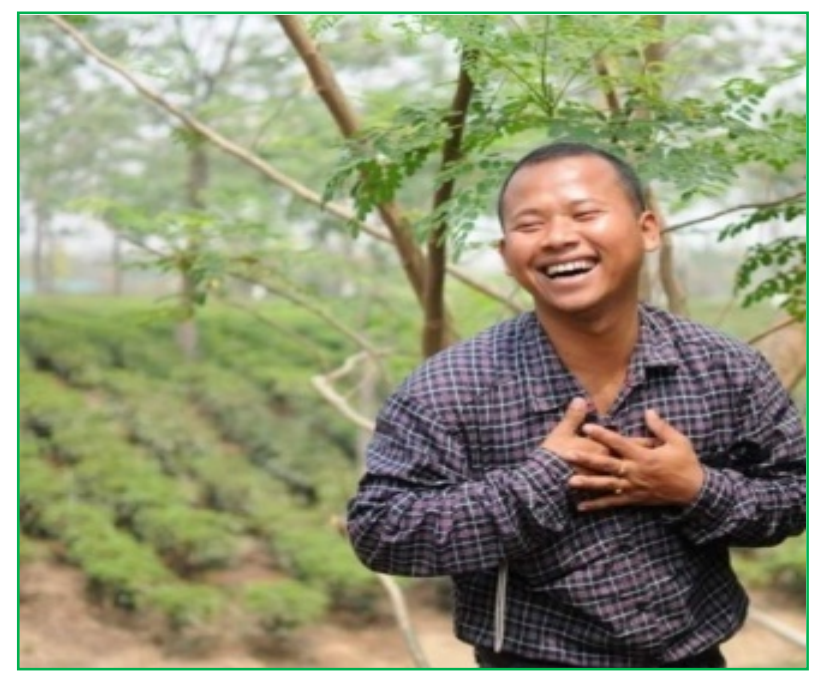

Figure 3. Mr Bodosa - Assam's First Organic Tea Farmer 


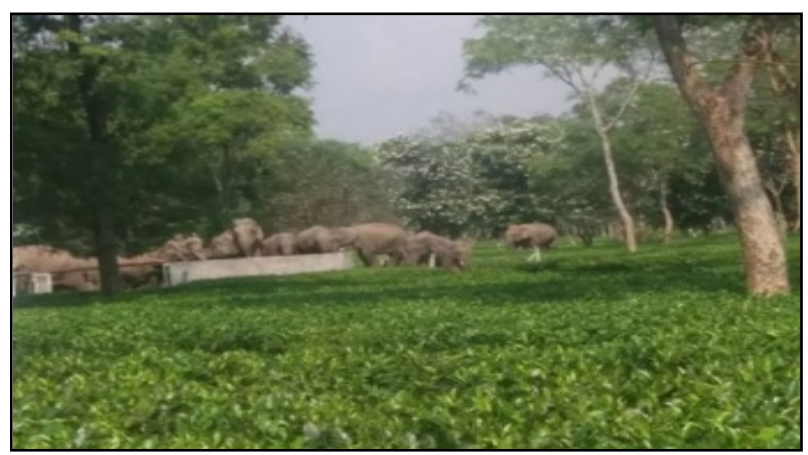

Figure 4. World's first elephant - friendly farms

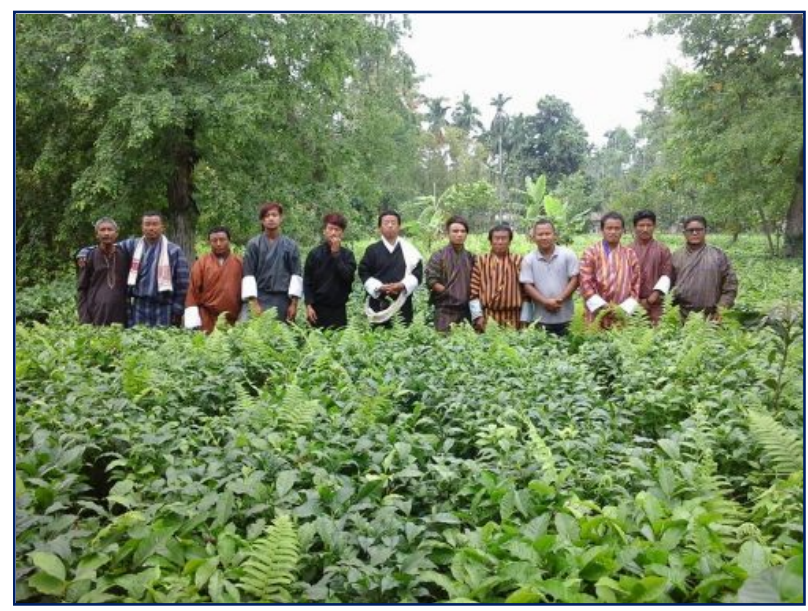

Figure 5. Mr Bodosa, his international recognitions

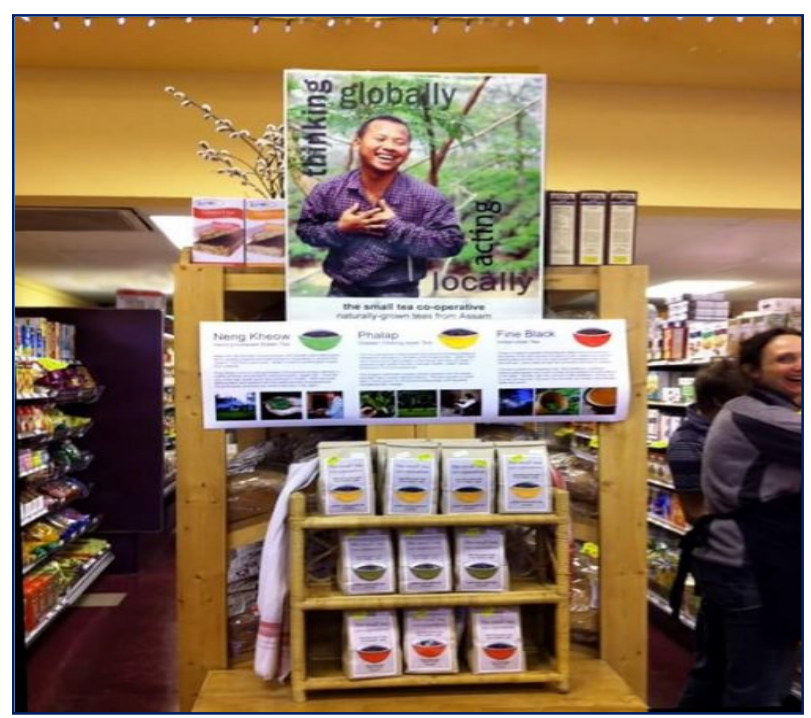

Figure 6. Mr Bodosa - his products

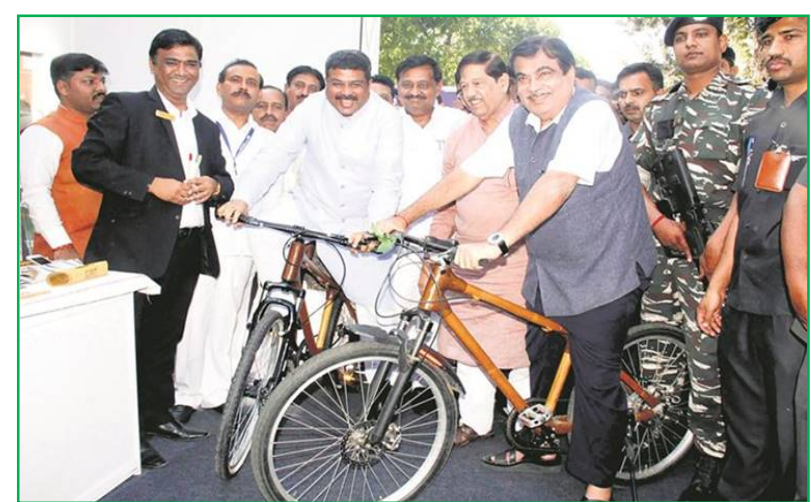

Figure 7. Bamboo cycles, designed by Bamboo India, Pune

\section{REFERENCES}

[1] Arunachal Pradesh Human Development Report 2005, [2006], Rajiv Gandhi University, Doimukh and the Arunachal Pradesh Human Development Report 2005, Summary, Pp. 44\&45, Department of Planning, Government of Arunachal Pradesh, Itanagar.

[2] Bula, H.O. (2012) "Evolution and Theories of Entrepreneurship: A Critical Review on the Kenyan Perspective", International Journal of Business \& Commerce, 1(11).

[3] Butola, (Undated): "Population Dynamics and Socio-Economic Development in North East India" Population Awareness Services, pp. 31-41.

[4] Census Report, 2011, Government of India

[5] Deb, Sukamal [2016]: Conflicting Status of Jhum cultivation and the Livelihood Rights - A Study with Reference to A.P.

(https://challenges.openideo.com/.../a8d9a6ec-cf9b-4da).

[6] Elwin, Verrier (1959): "A Philosophy for NEFA" Director of Research, Government of Arunachal Pradesh, Itanagar, $5^{\text {th }}$ reprint edition.

[7] en.wikipedia.org/wiki/northeast_India (Northeast_India-Wikipedia).

[8] gnrchospitals.com/

[9] Gunnar, Myrdal (1968): Asian Drama, Kalyani Publications, New Delhi, at P. 1290.

[10] Gupta, Dipankar [2007]: The Vanishing Village: Policy Implications for India in the Era of Globalization (https://www.wilsoncenter.org/.../the-vanishing-village). 
[11] Haridasan, K. and Rao, A.N. (1995): "Dendrobium Monticola - A Miniature Orchid New to N.E. India from Arunachal Pradesh", Arunachal Forest News, 13 (1\&2).

[12] http://en.wikipedia.org/wiki/Entrepreneur.

[13] http://karimganj.nic.in / www.kvic.org.in, Government of Assam. Cached

[14] https://yourstory.com/.../organic-team-farmer-tenzing

[15] http://www.businessdictionary.com/definition/entrepreneur ship.html.

[16] http://www.durgasolar.com

[17] http://www.thefinancialexpress-bd.com/2016/02/02/13689/

[18] https://bkbro.sarahah.com

[19] https://en.wikipedia.org/wiki/Binny_Yanga

[20] Indira Gandhi National Open University, New Delhi Study Materials for MA (Rural Development), year 2005, reprinted, 2007

[21] Indira Gandhi National Open University, New Delhi Study Materials for MA (Rural Social Development), year 2005, reprinted, 2008

[22] John W Keller [2001] : The Importance of Rural Development in the 21st Century - Persistence, Sustainability \& Futures

[www.regional.org.au/au/countrytowns/.../keller.htm]

[23] Joram, Begi [2008]: "Education Scenario in Arunachal Pradesh", Arunachal Review, Directorate of Information and Public Relation, Government of Arunachal Pradesh, Vol. X,[2], June -August, 2008, Itanagar.

[24] Lahkar, Sanjiv D. (2006): "North East Industrial Scenario" in Deorah Rajat (ed), North East Yellow Pages, Guwahati.

[25] Mishra, B.(2002): "Population Dynamics, Environment and Quality of Life in North-East", Published Article in web-site, www.iussp.org/Bangkok2002/S17Mishra.pdf

[26] News Paper Indian Express dated 25-11-2017

[27] News Paper Express News, Dimapur, Nagaland, October 6, 2016 (Neichute Doulo is Social Entrepreneur of the Year)

[28] owaap.org.in/ Website of Oju Welfare Association, Naharlagun, Arunachal Pradesh.

[29] Panda, N.M. (1988): "Emerging Trend of Population Growth in Nagaland", NEHU Journal of Social Sciences, Vol. VI (1), 99.55-64.

[30] Phukan, S. D. (1999): "Emerging Opportunities for Rural Employment Through Village Industries-Its Status in North East", Paper presented in a Seminar of KVIC at Guwahati.

[31] Report on Entrepreneurship Development Cell (EDC)
Sinhgad Technical Education Society's Sinhgad Academy of Engineering, Pune, India.

[32] Sachdeva, G. (2006): "North East: An Economic Profile" in Deorah Rajat (ed), North East Yellow Pages, Guwahati.

[33] Similar Singh, E. Bijoykumar: "Understanding Economic Growth in the North Eastern Region of India". Web site www.asthabharati.org/Dia_Jan\%2009/E.Bij.htmCached

[34] Statistical Abstract of Arunachal Pradesh, 2006, p-66 [Gazetteer of India, Arunachal Pradesh, Vol.-I, p 272-273].

[35] Story of 2000 organic micro entrepreneurs https://yourstory.com/2017/12

[36] The web site of National Institute for Entrepreneurship and Small Business Development. (NIESBUD), Strategic Action Plan for 2012-13 to 2016-17 (niesbud.nic.in).

[37] The web site of National Science \& Technology Entrepreneurship Development Board (NSTEDB), established in 1982 by the Government of India under the aegis of Department of Science \& Technology (www.nstedb.com).

[38] SimilarTrends and Patterns of Educated Unemployed Youth in North East, reimeingam. blogspot. com/2012/trends-and-patterns-of-educated.h, Cached You +1 'd this publicly. Undo15 May 2012, National Sample Survey data.

[39] Various publications of Entrepreneurship Development Institute of India, Ahmadabad

[40] www.janwaar-castle.com (Website of Janwaar Castle, Mr. Brijesh Kumar).

[41] www.kvic.org.in/update/KRDP/KRDP\%20Compendium_ 1.pdf (KRDP).

[42] www.mitticool.compak (website of Mitticool of Mr. Mansukh Prajapati)

[43] www.myworksolution.com (website of My Work Solution, Mr. Deepak Kumar)

[44] www.ruralcaravan.com (Website of Rural Caravan, Mr. Rohit Kumar Pillai).

[45] www.sanitarynapkinwholesale.com (Website of S.A. Enterprises, Mr. Afzal ShaiKh M.J.)

[46] www.servehappiness.org (website of Serve Happiness Foundation, Mr. Nitin Tailor)

[47] www.starforum.org (Website of Stars Forum, Skilled Training for Advancements in Rural Sciences).

[48] www.uravu.net (Website of Uravu, Indigenous Science \& Technology Study Centre)

[49] www.viganashram.com (Website of Vigyan Ashram). 